\title{
CORRESPONDENCE
}

\section{Automated rubella antibody screening: a cautionary tale}

In the UK, rubella vaccination is offered to seronegative adult women, identified by rubella antibody screening and, as measles, mumps and rubella vaccine (MMR), to children in the second year of life [1]. This policy has resulted in a decline in the number of cases of rubella in pregnancy and congenitally acquired rubella. Before the introduction of rubella vaccination there were $>100$ infants born with congenital rubella each year, compared with 4-5 per year in 1991-1995. Many of the women who acquired rubella in pregnancy in the 1990s were born outside the UK and probably were never offered rubella vaccination [2]. Uptake of MMR vaccine among children has declined since 1995 , partly due to anxiety about vaccine safety caused by adverse publicity. An increase in rubella incidence is now anticipated with consequent exposure of susceptible pregnant women; therefore it is important that susceptible women of child-bearing age are identified by rubella antibody screening.

Many laboratories use automated assays for rubella antibody screening. In our laboratory 12000 sera are tested annually for rubella antibodies with a fully automated microparticle enzyme-immunoassay (MEIA; Abbott Diagnostics). We use a cut-off of $12 \mathrm{IU} / \mathrm{ml}$, although $10 \mathrm{IU} / \mathrm{ml}$ is recommended by the manufacturers. According to the recommendation of a PHLS Working Party [3] we re-test sera with undetectable $(<5 \mathrm{IU} / \mathrm{ml})$ or a low level $(5-12 \mathrm{IU} / \mathrm{ml})$ of antibodies by latex agglutination (LA; Orion Diagnostica). There is normally good correlation between the LA and MEIA, but during the last few months occasional sera with antibody concentrations of $7-13 \mathrm{IU} / \mathrm{ml}$ on MEIA were negative on LA and confirmed as negative by LA and single radial haemolysis elsewhere.

As these findings caused some concern, we retrospectively examined our rubella antibody screening results for the previous 6 months, to find that 315 $(5.7 \%)$ of the 5446 sera tested gave antibody concentrations of $<12 \mathrm{IU} / \mathrm{ml}$ by MEIA. Concordant results were obtained for $87 \%$ of these by LA, but of 53 sera with results of $10-12 \mathrm{IU} / \mathrm{ml}$, three were negative and six gave weak positive results on LA. Thus, if we had been using $10 \mathrm{IU} / \mathrm{ml}$ as cut-off, as recommended by the manufacturer, we would have reported false positive results, albeit rarely $-9(0.17 \%)$ of 5446 sera. To avoid false positive results and the risk of susceptible women not being offered vaccination [4], we further increased the cut-off of our MEIA screening assay to $15 \mathrm{IU} / \mathrm{ml}$.

This problem highlights the need to retain laboratory staff with virological experience and expertise to interpret results and identify potential problems. It is important to remain vigilant and not to rely uncritically on automated assays, which are used increasingly for large-scale screening.

S. O'Shea, H. Dunn, S. Palmer, J. E. Banatvala, J. M. Best

Department of Virology, Guy's and St Thomas' Hospital Trust, London SE1 7EH, UK (e-mail: jenny.best@kcl.ac.uk)

\section{References}

1. Department of Health, Welsh Office, Scottish Office Department of Health, DHSS (Northern Ireland). Immunisation against infectious disease, 2nd edn. London, HMSO. 1996.

2. Tookey PA, Peckham CS. Surveillance of congenital rubella in Great Britain, 1971-96. BMJ 1999; 318: 769-770.

3. Anon. Laboratory Diagnosis of Rubella. Summary of recommendations of the PHLS Working Party. PHLS Microbiology Digest 1988; 5: 49-52.

4. Best JM, Banatvala JE. Rubella. In: Zuckerman AJ, Banatvala JE, Pattison JR (eds) Principles and practice of clinical virology, 3rd edn. Chichester, John Wiley and Sons. 1994: 363-400. 